\title{
Quality Enhancement of TIG Welded Al6061 SiCp Composites by Age Hardening Process
}

\author{
M. C. G. Shankar, P. K. Jayashree*, S. S. Sharma, R. Shetty and K. Vinay \\ Department of Mechanical Engineering, Manipal Institute of Technology, \\ Manipal Academy of Higher Education,Manipal,Karnataka, INDIA-576104 \\ *Email: jayashree.pk@manipal.edu \\ Phone: +91-9448783231, Fax: +91-820-2571071
}

\begin{abstract}
Aluminium and its alloys have exceptional corrosion resistant properties, simplicity of fabrication and extraordinary specific strength-to-weight ratio. The main objective of this study is to explore the effect of age hardening on the mechanical properties of tungsten inert gas (TIG) welded joints of the composite. This study highlights the enrichment in mechanical properties like hardness and tensile strength of TIG welded Al6061-SiC composites. A single-pass TIG welding using 5356 filler material is carried out on the composite with varying percentages of $\mathrm{SiC}$ having $25 \mu \mathrm{m}$. The hardness and tensile strength of the weld zone in as-weld condition is measured. The samples are then subjected to age hardening treatment at different temperatures and the peak hardness values are determined. The tensile strength is noted, and these values are compared with the values of the as-weld condition. The microstructure of the fracture surface in as-weld and peak aged condition is taken and the type of failure mode is found out. X-ray diffraction (XRD) spectra of the peak-aged sample is also considered for the analysis. The results indicated that there was significant influence leading to substantial improvement of hardness and tensile strength values of the samples after the age hardening process.
\end{abstract}

Keywords: Tungsten inert gas welding; Al6061 alloy; silicon carbide; composites; age hardening, microstructure.

\section{INTRODUCTION}

For many years Al6061 alloy has been widely used in automobile, aerospace and marine applications owing to its increased strength, superior weldability and resistance to corrosion. Aluminum MMCs reinforced with $\mathrm{SiC}$ particles have an improvement in the yield strength by up to $20 \%$, lesser thermal expansion coefficient, greater elasticity modulus and additional resistance to wear than the equivalent un-reinforced matrix alloy systems. Among various ceramic reinforcement materials, $\mathrm{SiC}$ and $\mathrm{Al}_{2} \mathrm{O}_{3}$ are extensively used in practice, in line for favourable combination of high refractoriness, high temperature dimensional stability and cost effectiveness [1].

Since properties of silicon carbide $(\mathrm{SiC})$ do not change in most aluminum alloys in the solid state, reactivity is not a concern for composites made with $\mathrm{SiC}$ as reinforcement for liquid aluminum. Silicon carbide, because of its elevation in stability, has acquired a number of applications including cutting tools, jewellery, automobiles, and electronic circuits. $\mathrm{SiC}$ is used as reinforcement in different forms such as particulates, whiskers or fibres to improve the properties of the composite. When 
embedded in metal matrix composites $\mathrm{SiC}$ positively increases the overall strength of the composite along with corrosion and wear resistance. Due to these reasons SiC particulate reinforced aluminium composites have several uses in brake discs, bicycle frames, aerospace and automotive engineering.

Welding processes are vital for the manufacture of a wide variety of products. TIG welding is commonly used when high quality and precision welding is required. Precipitation hardening is a heat treatment process for nonferrous metals and composites that augment the strength and rigidity of metal alloy by the development of extremely small evenly dispersed particles of second phase (intermetallics) surrounded by the unique phase matrix [2]. In the course of aging treatment of this alloy, the precipitation of metastable precursors of the equilibrium $\beta\left(\mathrm{Mg}_{2} \mathrm{Si}\right)$ phase takes place in one or other sequences which are relatively complex. The formation of the stable $\beta$ phase $\left(\mathrm{Mg}_{2} \mathrm{Si}\right)$ paves the way by a series of alterations comprising a number of coherent as well as semi-coherent meta-stable phases [3]. The present work focuses on enhancement of mechanical properties of the weld zone for the TIG welded composites by age hardening process.

\section{METHODOLOGY}

\section{Materials}

In the present study, composites are made of $\mathrm{Al} 6061$ reinforced with 7, 9 and $11 \mathrm{wt} . \%$ of SiC particulates (purity of $99.9 \%$ ), and $25 \mu \mathrm{m}$ size. Table 1 shows the chemical composition of Al6061 alloy and filler material. The specimen is made as per the BIS standard with $6 \mathrm{~mm}$ thickness having a groove angle of $60^{\circ}$. A single pass TIG welding is carried out by a servo mechanism speed controlled non-consumable electrode used to strike arc between the pieces to be welded. Welding process parameters and age hardening temperatures are as shown in Table 2.

Table 1. Chemical compositions of $6061 \mathrm{Al}$ alloy and filler material.

\begin{tabular}{|c|c|c|c|c|c|c|c|c|c|}
\hline Element (wt. \%) & $\mathrm{Si}$ & $\mathrm{Fe}$ & $\mathrm{Cu}$ & $\mathrm{Mn}$ & $\mathrm{Zn}$ & $\mathrm{Ti}$ & $\mathrm{Mg}$ & $\mathrm{Cr}$ & $\mathrm{Al}$ \\
\hline $\begin{array}{l}\text { Al } 6061 \text { (Base } \\
\text { metal) }\end{array}$ & $\begin{array}{c}0.40- \\
0.80\end{array}$ & $\begin{array}{l}0.70 \\
\text { Max }\end{array}$ & 0.24 & 0.15 & $\begin{array}{l}0.25 \\
\text { Max }\end{array}$ & $\begin{array}{l}0.15 \\
\text { Max }\end{array}$ & $\begin{array}{c}0.80- \\
1.20\end{array}$ & $\begin{array}{l}0.04- \\
0.35\end{array}$ & Balance \\
\hline $\begin{array}{l}\text { ER5356 } \\
\text { (Filler metal) }\end{array}$ & 0.25 & 0.40 & 0.10 & $\begin{array}{c}0.05- \\
0.20\end{array}$ & 0.10 & $\begin{array}{l}0.06- \\
0.20\end{array}$ & $\begin{array}{c}4.50- \\
5.50 \\
\end{array}$ & $\begin{array}{c}0.05- \\
0.20\end{array}$ & Balance \\
\hline
\end{tabular}

Table 2. Welding test parameters, ageing temperatures and their levels.

\begin{tabular}{cccccc}
\hline Level & $\begin{array}{c}\text { Welding } \\
\text { current }(\mathrm{A})\end{array}$ & $\begin{array}{c}\text { Welding speed } \\
(\mathrm{mm} / \mathrm{min})\end{array}$ & $\begin{array}{c}\text { Gas flow rate } \\
(\mathrm{L} / \mathrm{min})\end{array}$ & $\begin{array}{c}\text { SiC } \\
(\text { wt. \%) }\end{array}$ & $\begin{array}{c}\text { Ageing } \\
\text { temperature }(\mathrm{h})\end{array}$ \\
\hline 1 & 180 & 100 & 12 & 8 & 100 \\
2 & 200 & 120 & 14 & 10 & 150 \\
3 & 220 & 140 & 16 & 12 & 200 \\
\hline
\end{tabular}

\section{Age Hardening/ Precipitation Hardening Treatment}

The as-weld samples are cut into rectangular pieces, then solutionised at $558{ }^{\circ} \mathrm{C}$ for 2 hours and next water quenched at room temperature. Finally, the specimens are age 
hardened at $100{ }^{\circ} \mathrm{C}, 150{ }^{\circ} \mathrm{C}$ and $200{ }^{\circ} \mathrm{C}$ by varying the time and the hardness is checked. Three indentation readings in each specimen at different locations of the weld pool are taken and the average hardness is considered. The peak hardness is found out from the hardness verses time graph at the respective aging temperatures. According to the $\mathrm{Al}-\mathrm{Mg}-\mathrm{Si}$ phase diagram, melting of ternary eutectic $\mathrm{Mg}_{2} \mathrm{Si}-\mathrm{Al}-\mathrm{Mg}$ phase takes place at $558{ }^{\circ} \mathrm{C}$ [4]. The presence of $\mathrm{Mg}_{2} \mathrm{Si}$ in a solidification period and melting absolutely at $558{ }^{\circ} \mathrm{C}$ throughout solutionising precipitates in the course of age hardening to make best use of the strengthening effect. The minor precipitated levels result in particle strengthening and coherency of the crystal structure of the particle and the surrounding matrix. According to report Al6061-SiC composite, when solution heattreated at $558{ }^{\circ} \mathrm{C}$, reveals superior strength compared to the samples solution treated at $530{ }^{\circ} \mathrm{C}$ after aging treatment [5].

\section{Preparation of Tensile Test Specimen}

ASTM E8M standard tensile test specimens are prepared with rectangular cross-section of gauge length $45 \mathrm{~mm}$ as shown in Figure 1. Composite specimens at 7, 9 and $11 \mathrm{wt} . \%$ $\mathrm{SiC}$ were solution treated at $558{ }^{\circ} \mathrm{C}$ and peak aged at different aging temperatures of $100{ }^{\circ} \mathrm{C}, 150{ }^{\circ} \mathrm{C}$ and $200{ }^{\circ} \mathrm{C}$ as shown in Figure 3. Gauge length of the specimen is checked using vernier caliper and the cross-sectional area is calculated. The load cell of $20.5 \mathrm{kN}$ is reserved and the break mode is selected. Constant cross head speed of 10 $\mathrm{mm} / \mathrm{min}$ and distance increase of $0.01 \mathrm{~mm}$ are maintained.

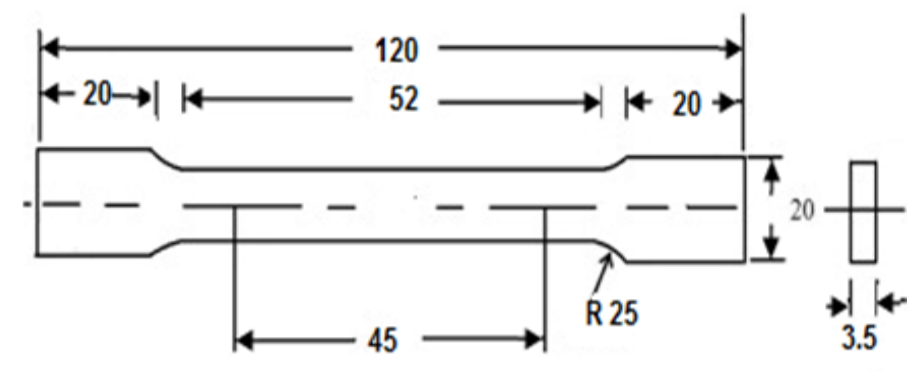

Figure 1. Specimen for tensile test (all dimension in $\mathrm{mm}$ ).

\section{Hardness Measurement}

Brinell hardness testing machine was used to test hardness having a steel ball indenter of diameter $5 \mathrm{~mm}$ and a load of $250 \mathrm{kgf}$ (SAROJ Brinell Hardness Testing Machine, Model: -B/3000/00, S1 \# 13/06/08- India) as per ASTM E10 standards.

\section{RESULTS AND DISCUSSION}

\section{Aging Curves and Hardness}

The specimens in as-weld and age hardened conditions are subjected to hardness test to find the hardness number (BHN). The peak hardness value achieved in as-weld and age hardened at $100{ }^{\circ} \mathrm{C}, 150{ }^{\circ} \mathrm{C}$ and $200{ }^{\circ} \mathrm{C}$ against time for the Al6061 alloy and Al6061$\mathrm{SiC}$ composites are shown in Figure 2. When compared with base alloy, the composites show severe escalation in peak hardness in the as-weld and heat-treated conditions as 
shown in Table 3. In as-weld condition the hardness value improves in line with adding reinforcements when matched with the unreinforced alloy. Similarly, in composites the as-weld hardness value escalates along with the increase in percentage of $\mathrm{SiC}$ as shown in Figure 2(b) to 2(d). It is because $\mathrm{SiC}$ elements are unbreakable dispersoid that definitely add to the hardness of the composite [6]. Increasing the reinforcement in the matrix alloy results in a greater number of dislocation densities in the course of solidification owing to the coefficient of thermal expansion disparity of matrix alloy and the reinforcement. This results in enormous internal stresses and non-uniform strain which disturbs microstructure and the mechanical properties of composites. The matrix distorts plastically toward providing accommodations for the less significant volume enlargement of the reinforcement particles resulting in the increased displacement density. Enrichment in dislocation masses effects in greater resistance for the plastic distortion which is accountable for the extra intensification in the hardness of composites [7].

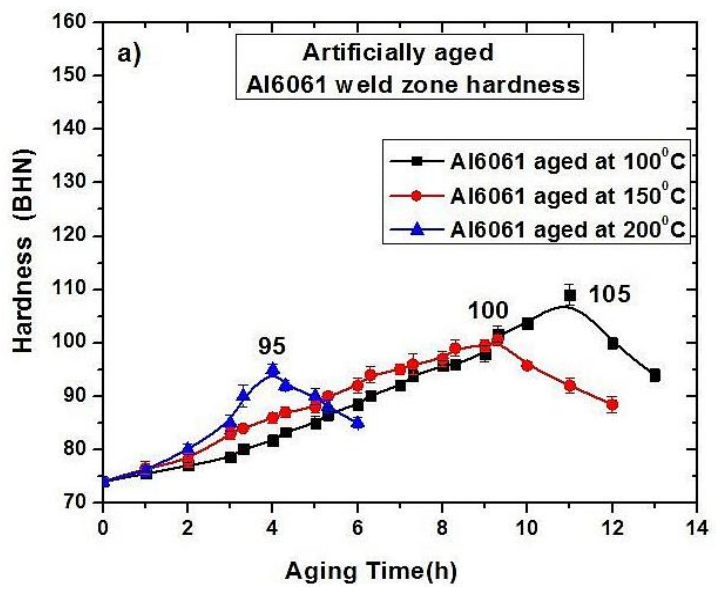

(a)

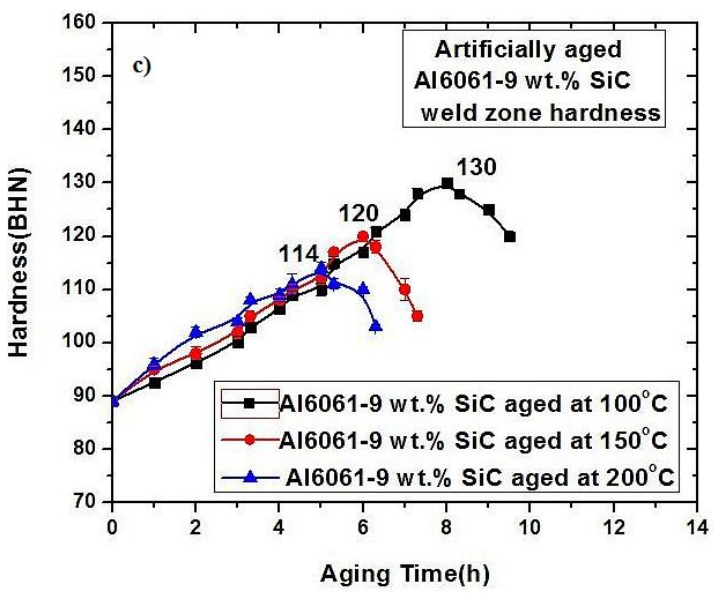

(c)

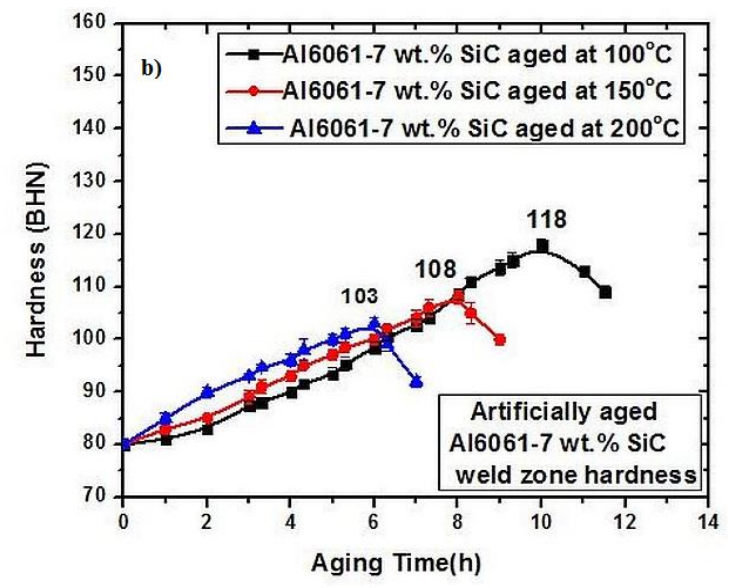

(b)

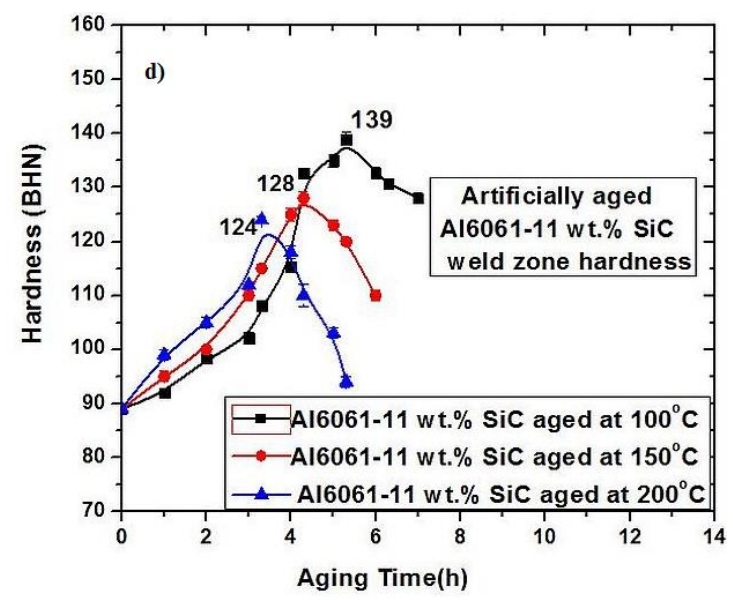

(d)

Figure 2. Hardness of weld zone for (a) Al6061 alloy, (b) Al6061-7 wt.\% SiC, (c) Al6061-9 wt.\% SiC; and (d) Al6061-11 wt.\% SiC composites peak aged at $100{ }^{\circ} \mathrm{C}$, $150{ }^{\circ} \mathrm{C}$ and $200^{\circ} \mathrm{C}$. 
Table 3. Hardness of Al6061-SiC composites at 0 wt. $\%, 7$ wt. $\%, 9$ wt. $\%$ and 11 wt.\% in as-weld and peak age hardened condition in weld zone.

\begin{tabular}{lcccc}
\hline Composite & \multicolumn{4}{c}{ Hardness (BHN) } \\
\cline { 2 - 5 } & $\begin{array}{c}\text { As weld (without } \\
\text { heat treatment) }\end{array}$ & $\begin{array}{c}\text { Peak aged at } \\
200^{\circ} \mathrm{C}\end{array}$ & $\begin{array}{c}\text { Peak aged at } \\
150{ }^{\circ} \mathrm{C}\end{array}$ & $\begin{array}{c}\text { Peak aged at } \\
100^{\circ} \mathrm{C}\end{array}$ \\
\hline Al6061-0\%SiC & 85 & 95 & 100 & 105 \\
Al6061-7wt,\%SiC & 90 & 103 & 108 & 118 \\
Al6061-9wt.\%SiC & 100 & 114 & 120 & 130 \\
Al6061-11wt.\%SiC & 117 & 124 & 128 & 139 \\
\hline
\end{tabular}

The strength of Al6061 alloy and Al6061-SiC composites can be further enhanced by the precipitation hardening shown in Figure 3 (b) to 3(d) under different aging temperatures. Higher values of hardness highlight the superiority of age hardening kinetics with increased $\mathrm{Mg}$ content at the joints. The increased $\mathrm{Mg}$ content increases the $\mathrm{Mg}$ rich intermetallic. Optimum aging increases the number of precipitate particles. Fine and uniform dissemination of precipitates at the weld joints that are attained by applying heat treatment by other means of noble features of TIG welding process like spatter free welding is liable for the rise in hardness.

The increase in temperature from $100{ }^{\circ} \mathrm{C}$ to $200{ }^{\circ} \mathrm{C}$ causes the ageing speed to increase due to the improved frequency of diffusion of atom in the matrix. Since matrix is a strong age hardenable alloy, it is expected that $\mathrm{SiC}$ reinforced Al6061 alloy composites may be too sensitive to age hardening irrespective of aging temperatures. Among all aging temperatures, aging at $100{ }^{\circ} \mathrm{C}$ for both base alloy and its composites shows higher peak hardness values although the time intervals for achieving peak aging are considerably higher.

Lower age hardening temperature of $100{ }^{\circ} \mathrm{C}$ shows an improvement in the hardness of base alloy and the composites in comparison to high temperature aging as shown in Figure 2(a) to 2(d). Low temperature age hardening yields better resistance by increasing the total amount of transitional zones in the course of precipitation, rise in quantity of the finer intermetallic and reduced inter-particle distances. The hardness value decreases after peak aging condition, due to coarsening of precipitates which form during aging - this condition is termed as over-aging. Over-aging induces softness due to incoherency between the precipitates and alloy matrix which reduces lattice strain, hence hardness value decreases [5-7]. Higher temperatures of $150{ }^{\circ} \mathrm{C}$ and $200{ }^{\circ} \mathrm{C}$ accelerate the aging rate due to the enhanced rate of diffusion in the matrix. The higher the aging temperature, the lower is the time required to attain peak hardness [5]. The above outcomes conclude that heat treatment is found to have a deep impact on the hardness of matrix alloy, making it as good as composites.

\section{Tensile Strength}

Table 4 shows the UTS values of the composites. It shows that there is an escalation in ultimate tensile strength by the addition of reinforcements when compared with that of unreinforced alloy as in as-weld condition. The mechanical property is controlled by the reinforcement particles due to the strong interface, which dispenses load from matrix to the reinforcement showing improved elastic modulus and strength. A similar behavior was noticed for a marginal increase in the strength of Al6061-SiCp composites [8]. This 
escalation in UTS is due to the existence of SiC particles acting as hurdles to the dislocation movement.

Table 4. Ultimate tensile strength of as-weld and peak aged composites.

\begin{tabular}{lcccc}
\hline Composite & \multicolumn{4}{c}{ Ultimate tensile strength (MPa) } \\
\cline { 2 - 5 } & $\begin{array}{c}\text { As-weld (without } \\
\text { heat treatment) }\end{array}$ & $\begin{array}{c}\text { Peak aged at } \\
200{ }^{\circ} \mathrm{C}\end{array}$ & $\begin{array}{c}\text { Peak aged at } \\
150{ }^{\circ} \mathrm{C}\end{array}$ & $\begin{array}{c}\text { Peak aged at } \\
100{ }^{\circ} \mathrm{C}\end{array}$ \\
\hline Al6061-0\%SiC & 160 & 200 & 207 & 220 \\
Al6061-7wt.\%SiC & 165 & 210 & 218 & 225 \\
Al6061-9wt.\%SiC & 172 & 228 & 232 & 238 \\
Al6061-11wt.\%SiC & 179 & 242 & 254 & 260 \\
\hline
\end{tabular}

The UTS of Al6061-7 wt.\% SiC is $225 \mathrm{MPa}$ when aged at $100{ }^{\circ} \mathrm{C}$ and $165 \mathrm{MPa}$ in as-weld condition. Whereas, UTS of Al6061-11 wt.\% SiC is $260 \mathrm{MPa}$ when aged at $100{ }^{\circ} \mathrm{C}$ and $179 \mathrm{MPa}$ in as-weld condition. It was observed that during lower aging temperature there is a maximum of $60 \%$ additional rise in UTS of composites when compared with the as-welded condition. From the graph shown in Figure 3, it is understood that the higher the weight percentage of reinforcement in the composite and lesser aging temperature, the superior is the final tensile strength. The increase in strength is because of the collective effect of dissimilarity in the coefficient of thermal expansion amongst matrix and $\mathrm{SiC}$ particulates and precipitation activities of solute rich secondary phases [5].

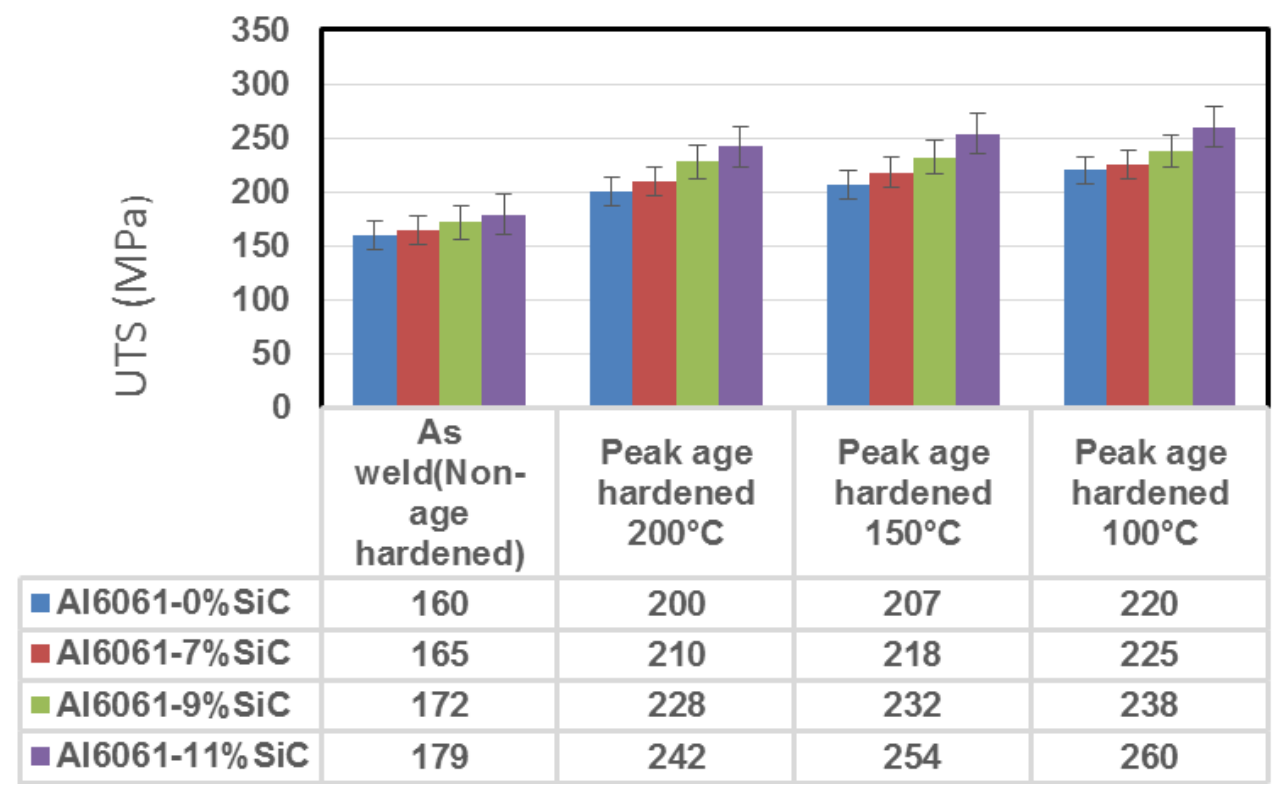

Figure 3. Variation of the tensile strength with increasing content of SiC particulates under different ageing conditions

From the experimental data, it is clear that the tensile properties of the welded joint have improved to a significant extent by the aging process. This marked improvement in tensile strength of Al6061-SiC composites is due to the formation of intermetallic precipitates (coherent or semi-coherent $\mathrm{Mg}_{2} \mathrm{Si}$ ), which act as the points of obstacles to dislocation movement and hence lead to increase in dislocation length and 
multiplication of dislocations (Frank-Reed source). This phenomena of development of dislocations curbs the movement of dislocations, thereby reducing the degree of plastic deformation. This leads to substantial enhancement in UTS [9].

SEM images of fracture surface of the tensile specimen of both as-weld and peak aged $\left(100{ }^{\circ} \mathrm{C}\right)$ composite with $11 \mathrm{wt} . \% \mathrm{SiC}$ is shown in Figures 4 and Figure 5. The overall fracture in as-weld composite is mixed mode in nature shown in Figure 4(a) to 4(c). The composite material undergoes failure with a mechanism of void nucleation, growth and amalgamation. Fractography of the weld composites reveals the exposed $\mathrm{SiC}$ on the fracture surface indicating the failure of MMC predominantly through the matrix. Also, in few locations the failure mode of the investigated metal matrix composites is through the particle-matrix interface cracking. Mode of fracture is mainly due to improper interface bonding and void nucleation growth. This is mostly due to the creation of strain localisation at the sharp places of the SiC particles. The coalescence of the voids was taking place in the course of tensile loading causing the development of Void Nucleation Growth (VNG) failure at the fractured area during severe crack propagation [10-14] around the weaker matrix grain. Corresponding EDAX analysis shown in Figure 4(b)-(c) is composition of $\mathrm{SiC}$ and matrix materials.

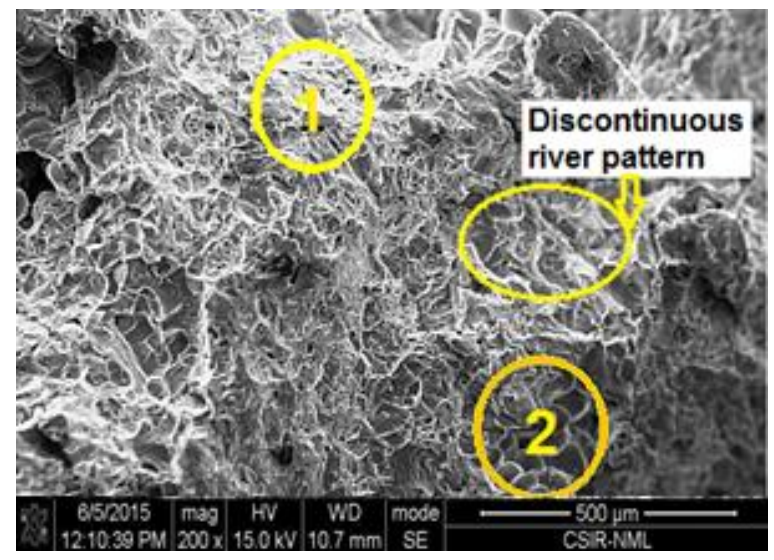

(a)

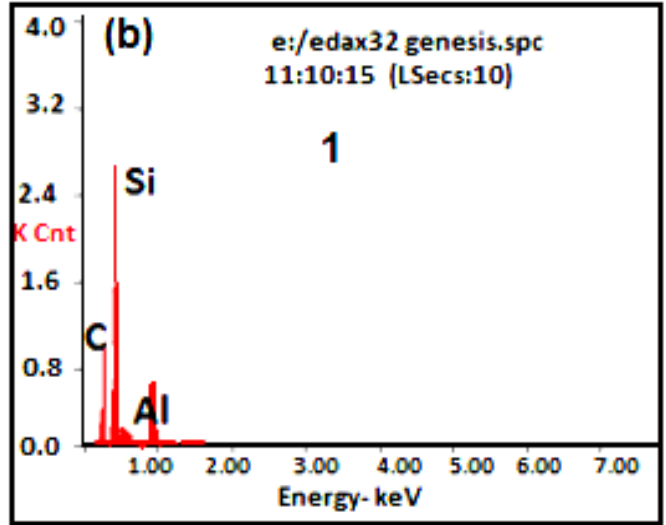

(b)

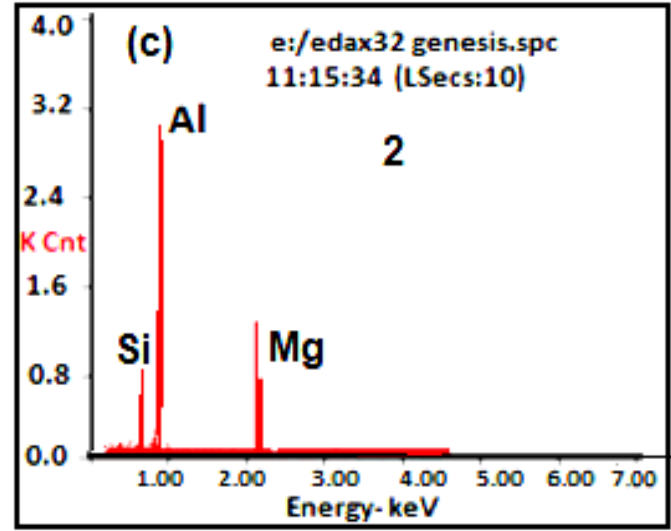

(c)

Figure 4. (a) SEM micrograph of fracture surface in the as-weld A16061-11 wt.\% SiC composite and corresponding EDAX analysis of (a) SiC particles and; (c) Al6061 alloy

The peak aged composite shows mixed mode fracture similar to as-weld condition as shown in Figure 5(a) to 5(b). The dimples are finer than that of its 
counterpart. Finer dimples array is the indication of higher strength and hardness. In few locations river-like patterns are also observed as the result of ductile fracture shown in Figure 6(b). The dimples and river-like pattern observed reflects that the failure mode is the combination of both ductile and brittle (mixed) nature. But in some locations coarse dendritic structures is also observed. It may be due to the presence of harder SiC reinforcement particles and presence of intermetallic during age hardening. Since no particle matrix interface fracture is observed, the failure is mainly due to the intergranular fracture. Figure 5(c) - 5(d) shows corresponding EDAX analysis of the composition of $\mathrm{SiC}$ reinforcement and matrix alloy in the weld zone.

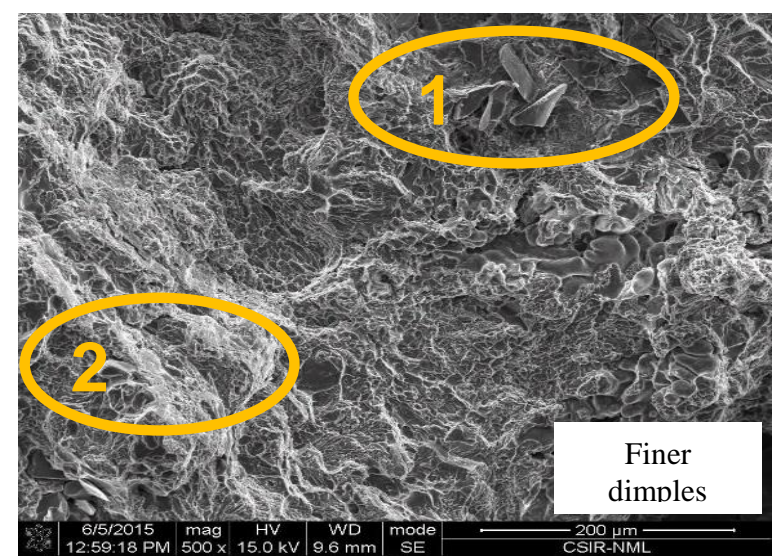

(a)

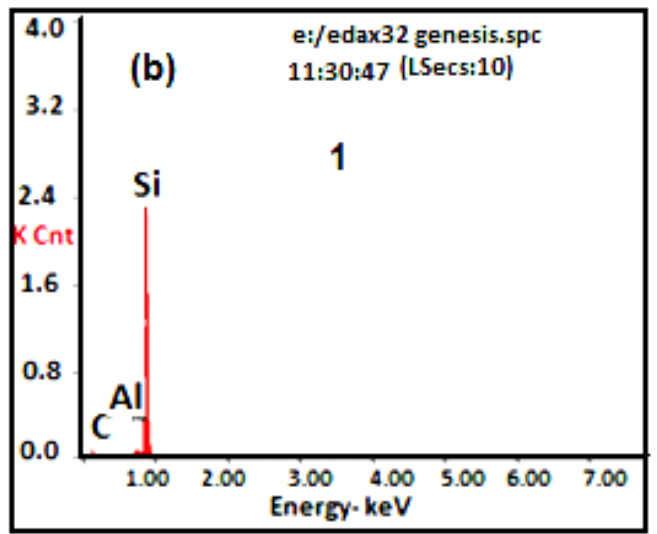

(b)

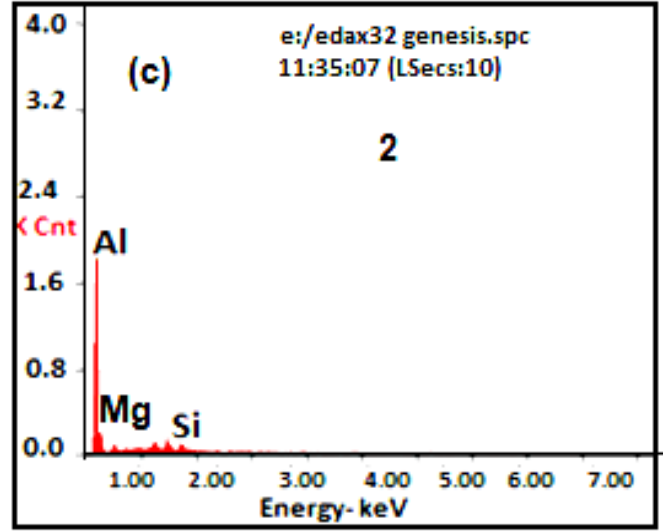

(c)

Figure 5. (a) SEM micrograph of fracture surface in the welded Al6061-11wt.\% SiC composite (peak aged at $100^{\circ} \mathrm{C}$ ) and corresponding EDAX of (b) $\mathrm{SiC}$ particles and; (c) Al6061 alloy

Figure 6 shows the XRD spectra of the peak aged sample with the precipitation of $\mathrm{Mg}_{2} \mathrm{Si}$ intermetallic in Al6061-11wt.\% SiC metal matrix composite in addition to aluminium matrix and silicon. 


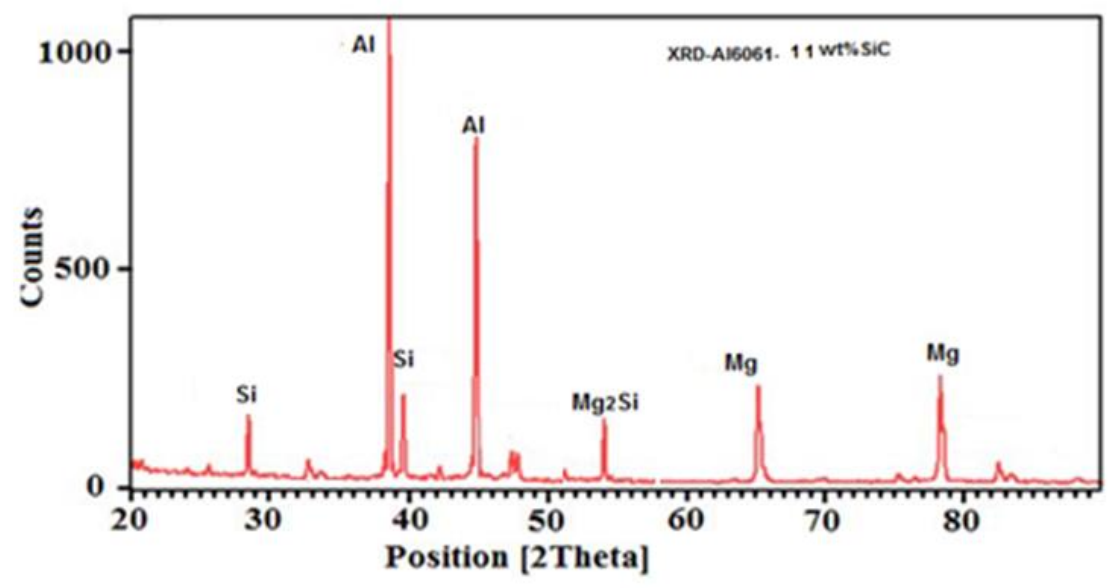

Figure 6. XRD spectra of Al6061-11wt\%SiC at peak aged condition.

\section{CONCLUSION}

Inferences drawn from the present study are that in as-weld state, the hardness increases by $20 \%$ due to the presence of reinforcement when compared with the base alloy. A16061 alloy and A16061-SiC composites responds positively to age hardening with substantial improvement in mechanical properties. An escalation in peak hardness of (30-40) \% (7, 9 and 11 wt.\% SiC) aged at $200{ }^{\circ} \mathrm{C}$ and (50-60) \% (7 wt.\%, 9 wt.\% and 11 wt.\% SiC) when aged at $100{ }^{\circ} \mathrm{C}$ is observed in a significant time period for the composites in comparison with untreated Al6061 alloy. Marginal increase of (15-30) \% in the tensile strength (UTS) is observed in as-weld Al6061-SiCp composite when compared to as-weld Al6061 alloy. After aging there is (60-80) \% increase in UTS of composites aged at $100{ }^{\circ} \mathrm{C}$ and (40-50) \% increase in UTS value when aged at $200{ }^{\circ} \mathrm{C}$ compared with untreated base alloy. Untreated as-weld Al6061-11 wt.\%. SiC tensile fracture surface exhibits mixed mode (brittle and ductile), void nucleation growth (VNG) failure and also particle-matrix interface cracking. Peak aged tensile fracture surface of Al6061-11 wt.\% SiC exhibits mixed mode of failure, with coarse dendritic structures. It was observed that there was no particle matrix cracking and the failure was mainly due to intergranular fracture.

\section{REFERENCES}

[1] Muhamad HH, Nur ACL. Effects of temperature on the surface and subsurface of Al-Mg-Si welded joints. Journal of Mechanical Engineering and Sciences, 2017; 11(2): 2743-2754.

[2] Ramakoteswara RV, Ramanaiah N, Srinivasa RM, Sarcar MMM, Kartheek G. Optimization of process parameters for minimum volumetric wear rate on AA7075-TiC metal matrix composite. International Journal of Automotive and Mechanical Engineering, 2016; 13(3): 3669-3680.

[3] Fahrettin O, Emre E, Serkan TC, Picu R. Effects of aging parameters on formability of 6061-O alloy. Materials and Design, 2010; 31: 4847-4852.

[4] Peng D, Shen J, Tang Q, Wu CP, Zhou YB. Effects of aging treatment and heat input on the microstructure and mechanical properties of TIG-welded 6061-T6 alloy joints. International Journal of Minerals,Metallurgy and Materials, 2013; 20(3):259-265. 
[5] Rajasekaran S, Udayashankar NK, Nayak J. T4 and T6 treatment of 6061 Al-15 Vol.\% SiC composite 2012. ISRN Materials Science 1-5.

[6] Veeresh Kumar GB, Rao CSP, Selvaraj N, Bhagyashekar MS. Studies on Al6061-SiC and Al7075- $\mathrm{Al}_{2} \mathrm{O}_{3}$. Journal of Minerals \& Materials Characterization \& Engineering, 2010; 9(1): 43-55.

[7] Salleh MNM, Ishak M, Romlay FRM, Aiman MH. A study on bead-on-plate welding of AA7075 using low power fiber laser. Journal of Mechanical Engineering and Sciences, 2016; 10(2): 2065-2075.

[8] Hussain F, Abdullah S, Nuawi MZ. Effect of temperature on fatigue life behavior of aluminium alloy AA6061 using analytical approach. Journal of Mechanical Engineering and Sciences. 2016; 10(3):2324-2235.

[9] Prabhu S, Ramesh CS, Chandrasekhar. Effect of heat treatment on strength and abrasive wear behaviour of Al6061-SiCp composites. Bulletin Material Science, 2010; 33(1):49-54.

[10] Herbert MA, Das G, Maiti R, Chakraborthy M, Mitra R. Tensile properties of cast and mushy state rolled Al-4.5 $\mathrm{Cu}$ alloy and in situ $\mathrm{Al} 4.5 \mathrm{Cu}-5 \mathrm{TiB}_{2}$ composite. International Journal of Cast Metals Research, 2015; 23(4): 216-224.

[11] Nagesh DS, Datta GL. Genetic algorithm for the optimization of welding variables for height to width ratio and application of ANN for prediction of bead geometry for TIG welding process. Applied Soft Computing, 2010; 10: 897-907.

[12] Mrowka N, Sieniawski J, Nowotnik A. Tensile properties and fracture toughness of heat treated 6082 alloy. Journal of Achievements in Materials and Manufacturing Engineering, 2006; 17(2): 105-108.

[13] Siddiqui RA, Abdul WSA, Pervez T. Effect of aging time and aging temperature on fatigue and fracture behavior of 6063 aluminum alloy under seawater influence. Materials and Design 2008; 29(1): 70-79.

[14] Ehsani R, Reihani SS. Aging behavior and tensile properties of squeeze cast Al6061/SiC metal matrix composites. Scientia Iranica 2004; 11(4): 392-397. 